\title{
How to Do Things with Literature in the Digital Age: Anne Carson's Nox, Multimodality, and the Ethics of Bookishness
}

\section{LIEDEKE PLATE}

\begin{abstract}
This article focuses on Nox (2010), an experimental, multimodal work that is a replica of the scrapbook Anne Carson made in memory of her recently deceased brother, Michael. So far, Nox has received relatively little critical attention. This essay aims to redress this lacuna. First, it places the work in the context of the digital moment, discussing its material and memorial dimensions, exploring its citational poetics, and inquiring into the reading strategies it elicits. Nox indeed comes folded concertina style, and it contains photographs, paintings, drawings, collages, a letter her brother once wrote home, and bits of text composed, photocopied, and stapled, the textures of the handcrafted original painstakingly reproduced to evoke the analog. Translating and parsing Catullus's elegiac poem 101 into lexicographical entries, Nox embodies a theory of "moving words": carrying them across languages, transporting them to new contexts, making them convey meaning; but also, moving readers affectively, cognitively, and physically. Second, taking its cue from cultural material studies, the article explores the book's materiality as a medium of sociality. Attesting to its social agency, the many pictures of the book that can be found on the Internet are claimed to display at once the artfulness of Nox and the (un)creativity of its readers. Approaching the book from the angle of peopleobjects relations, the article concludes that the bookishness of Nox is ethical because its aesthetics entail an indebtedness to the other with which it is "intra-actively" entangled.
\end{abstract}

Texts that employ their bodies to create narrative complexity must be read not for their words alone but for the physical involvements readers undertake to access their materialities. 


\section{Introduction}

Enabled by new technologies that make it possible to print images and word-image combinations more easily and cheaply than ever before (Gibbons, "Multimodal Literature" 420), literary works experimenting with the form of the book and the materiality of the printed page are increasingly present on today's mainstream publishing market. Produced by major publishers in relatively large print runs, such "bookish" works appropriate the aesthetics of the artist's book without participating in its exclusivity: the artist's book "integrates the formal means of its realization and production with its thematic or aesthetic issues" (Drucker, The Century of Artists' Books, 2). Often produced as a unique, one-of-a-kind handcrafted original work of art, or small edition, it "is conceived and executed as a book and does not exist in any other form or format" (Drucker, "Intimate Authority" 16). The experimentations with the print-based novel of, for example, Mark Danielewski's House of Leaves (2000) and Jonathan Safran Foer's Extremely Loud and Incredibly Close (2005) and Tree of Codes (2010), have been the object of a number of academic articles to date. However, scant critical attention has gone to the multimodal experimentations of women writers, such as Susan Howe's The Midnight (2003), Marisha Pessl's Special Topics in Calamity Physics (2006), or Anne Carson's Nox (2010): the September 2014 MLA Bibliography lists close to fifty entries for Danielewski and Foer, seven for Howe, one for Pessl, and none for Carson. Often genre-defying, multimodal literature by women seems to bear out Christine Brooke-Rose's claim that it is more difficult to be accepted for a woman experimental writer than for a woman writer or a male experimental writer (26I-62). This may be due to the domestic associations of multimodal literature, as it involves activities that "are in many ways connected to the traditionally sanctioned women's pursuits of keeping diaries, sewing, fancy needlework, elaborate decorative tasks, and the careful preservation of memory" (Drucker, "Intimate Authority" I4). In this article, I consider the aesthetic of bookishness in Carson's poetic multimodal work Nox, both to counter the focus on texts authored by men and to attend to the question of gender in experimental literature. Very little critical writing has been published on Nox. In "Multimodal Metaphors in Contemporary Experimental Literature," Alison Gibbons discusses Nox to illustrate the ways in which multimodal conceptual metaphors work, and in "Re-vision as Remediation: Hypermediacy and Translation in Anne Carson's Nox," Kiene Brillenburg Wurth examines it in the light of remediation. In contrast, I take a material culture studies perspective and explore its experimenting with the materiality of the book in the light of people-objects relations.

\section{Bookishness and the Rematerialization of Literary Studies}

"We begin to confront the thingness of objects when they stop working for us," Bill Brown explains in his essay "Thing Theory" (4). Brown's understanding of the 
1 See "The Origin of the Work of Art" and "The Thing," in Poetry, Language, Thought.

ways in which objects work is indebted to Heidegger's thinking about things, and it is akin to what anthropologist Daniel Miller has termed "the humility of things," by which he means that objects are important precisely because (and when) we do not see them. As he explains,

The less we are aware of them, the more powerfully they can determine our expectations, by setting the scene and ensuring appropriate behaviour, without being open to challenge. They determine what takes place to the extent that we are unconscious of their capacity to do so. (50)

Books are such objects. In the literature classroom and outside, books have done their work "by being invisible and unremarked upon," which result from "being familiar and taken for granted" (50). Literary theories, analyses, and interpretations have concentrated on texts, defined as linguistic artefacts, looking into their aesthetic, social, and semiotic dimensions, but more often than not paying little to no attention to the material form in which these texts came to us. For many of us, print books are part of what makes us readers, an "exterior environment that habituates and prompts us" (5I).

Electronic digital computing ended the invisibility of books. Bringing the text's material support back into view, e-books and e-readers reveal how the materiality of books has been a neglected area in literary studies and the reception of literary works. Of course, there are disciplines, such as the history of the book and the sociology of literature, that do inquire into the production, transmission, circulation, and dissemination of texts as a material practice, but as sociology and social and cultural history, these disciplines fall beyond the scope of literary studies as traditionally defined: "The understanding and preservation of literary texts" (Trimpi 187). Today, however, there is increasing recognition of literature as part of a broad media ecology, and literary studies as part of media studies broadly conceived - witness Katherine Hayles and Jessica Pressman's argument for a paradigm shift in the humanities to comparative textual studies, for instance, making a case for studying textual media from a media standpoint in Comparative Textual Media: Transforming the Humanities in the Postprint Era (2013).

Materiality stands at the heart of contemporary writing that foregrounds the sensory and affective dimensions of reading - experimental multimodal writing, that is, that not only draws attention to the text's visual and aural aspects but also to the ways in which the feel, touch, shape, weight, and smell of the bound paper page is part of its aesthetics, eliciting affect, emotions, and knowledge. Foregrounding the process of reading and intensifying the physical act of engaging with the book (Gibbons, "Multimodal Literature" 42I), such works present a reflection on the book and on the act of reading in the digital age. Jessica Pressman contends that the "aesthetics of bookishness" is to be read as a response to the digitization of our world. One can only concur that the spate of recent "novels that exploit the power of the print page in ways that draw attention to the book as a multimedia format, one informed by and connected to digital technologies" 
(Pressman 465) is to be understood in the context of what media scholar Henry Jenkins has termed "convergence culture," by which he means "the flow of content across multiple media platforms, the cooperation between multiple media industries, and the migratory behavior of media audiences" (2). Certainly, there is nothing new to experimental writing that focuses on the materiality of the book and explores texts as literary objects: suffice to remember Lawrence Sterne's play with the conventions of the codex and the possibilities of printed text in Tristram Shandy to see that there is a body of writing that has always known literature to be more than text. What is new, however, is the context of production and of reception. Today, literature is part of a media ecology characterized by digitalization and the cooperation between media industries. Digital media are involved at every stage of the production and distribution of literature. More importantly, the virtualization of text and its transformation into "content" to be distributed across multiple media and platforms have radically transformed the book publishing industry, which now collaborates with other industries such as film, clothing, games, toys, and tourism. Consequently, in the twenty-first century, the print book is but one "output form" of the text (Hayles 226). It is one thing the industry does with literature.

According to Pressman, the aesthetic of bookishness is the book fighting back, "fighting the good fight against the threat of the death of all things bookish: books, reading, and literature" (477). Using a vocabulary she derives from "bookish" authors such as Danielewski, Hall and Foer, all three of whom have claimed to have created books that cannot exist online, Pressman locates innovation in resistance. She argues, taking Steven Hall's The Raw Shark Texts as her example, that it is "the threat of the print body's demise that prompts book-bound literature to respond with the necessary vigor to fight for its life" (469). More arrière-garde (rearguard) than avant-garde (vanguard), then, the aesthetics of bookishness is thus understood as resistance to change, a last-ditch attempt to avert the inevitable unravelling of the sacred union of "books, reading, and literature." It is, in other words, nostalgia for a specific moment in the history of the book and of the sociology of reading mistaken as literary reading's eternal truth and natural habitat.

"[P]rint books have bodies," Hayles writes in her essay on the aesthetics of bookishness in Tree of Codes (226). Echoing Foer's claim that "'this is a book that remembers it has a body.' When a book remembers, we remember. It reminds you that you have a body" (qtd. in Wagner), she calls for a "reader-response theory that takes the mind-body fully into account" (23I). To be sure, the relationship between texts and (gendered) bodies is fraught and far from clear-cut, and so is that between bodies and books as the texts' material support. Therefore, I will not assume an a-priori relationship between gender and textual production. Given the absence of women from surveys of experimental writing (Friedman 154; but see the volume in which this article is published, the more than 500-pages-long Routledge Companion to Experimental Literature, which reproduces the marginalization of women's innovative writing), however, an absence that I read as an effect of gender 
socialization, norms, expectations, and context on the reception of women's writing, I ask: To what extent would another set of authors yield a different language for theorizing the aesthetics of bookishness? What would happen if we were to take Carson's Nox as our tutor text (rather than The Raw Shark Texts, as does Pressman, or Tree of Codes, as does Hayles) to inquire into contemporary experiments with the materiality of literature? To answer these questions, I follow another thread of Pressman's argument and, taking my cue from material culture studies, propose to approach the subject of bookishness from the angle of people-objects relations. If I am struck by the (conceptual) metaphor of battle and of struggle that frames Pressman's understanding of the aesthetic of bookishness, I am equally struck by the way in which this metaphor grants books agency by anthropomorphizing them. Such anthropomorphism, Jane Bennett maintains in Vibrant Matter, is necessary as a corrective to anthropocentrism: "to counter the narcissism of humans in charge of the world" (xvi). A "strategic anthropomorphism," then, analogous to Gayatri Spivak's "strategic essentialism," it seeks not to assert anthropomorphism but rather posits it as temporarily necessary. Less about fighting back or fighting for life understood as a physical body, the aesthetics of bookishness is about books asserting themselves as material culture. As I shall argue, Nox shows its bookishness to be about being and relationality, a "relational materiality" (Hodder 9l) understood to encompass interpersonal relations, the relations among things, and those between people and things. This is akin to Karen Barad's "intra-action," a neologism she coins to speak of the ways phenomena emerge intra-actively, that is, constitute each other as they come into being. Because, Barad explains, such "[e]ntanglements are relations of obligation - being bound to the other" (217; original emphasis), I submit that the bookishness of Nox is an experimental aesthetics that is also an ethics.

\section{Nox's Multimodality and the Materiality of Literature}

Gibbons has explored what Pressman and Hayles call the aesthetics of bookishness under the name "multimodality." Multimodal literature, she writes, "experiment[s] with the possibility of book form, playing with the graphic dimensions of text, incorporating images, and testing the limits of the book as a physical and tactile object" ("Multimodal Literature" 420). Referring to the work of Wolfgang Hallet, Gibbons explains that in multimodal literature, writing becomes designing, and reading becomes performing and the transmodal construction of meaning (42I), which requires the integration of various literacies and "the ability to decipher not only verbal language but also other codes and languages" (Hallet 150). As the role of the narrator shifts from narrating to presenting, showing found, retrieved, or collected documents and sources, multimodal literature "often pushes at its own ontological boundaries, [. . .] challenging readers in both cognitive and physical terms" ("Multimodal Literature" 420-2I). 
2 See Susan Sontag's "Notes on Camp."

3 As explained on HowStuffWorks, analog recordings degrade over time. See also Teicher, "A Classical Poet, Redux.”
Anne Carson's Nox (2010) is such a multimodal work. A replica of the scrapbook Carson originally made as a means of dealing with her brother Michael's sudden death, Nox comes folded concertina style in an ash-grey box of solid cardboard. It is made of twenty-seven sheets of thick white paper of 21 by 93 centimetres, glued together to make one long scroll of circa 25 metres that is folded like an accordion. The work is printed on one side of the paper; the reverse is blank. Design is an integral part of its making; inside the box, following a brief biography of the author, Robert Currie, the author's partner, is acknowledged as having "assisted in the design and realization of the book" (n. pag.). Nox can be read as one would read a conventional book - a "codex," that is - turning one folded page at a time to read each page or pair of pages individually. In fact, images of a ten-hole stitch binding at the internal fold reinforce the book codex-effect, suggesting this is a more than legitimate way of reading it. However, Nox, can also be unfolded so as to reveal its continuous nature; or, alternatively, the pages can be viewed in noncontiguous groups, creating the possibility for the reader to form her own arrangement of pages and, with that, her personal book divisions. A versatile work, then, its design reopens the print-based book to a plurality of material reading practices. Manifold, that is - the word is etymologically constituted of many + folds, which defines Nox exactly. Yet in this context, it can also be read as mani (hand) + fold - and totally "un-Kindle-izable." As Carson observes with noted pleasure (qtd. in Sehgal), Manifold, that is - the word is etymologically constituted of many + fold, which defines Nox exactly, yet in this context, it can also be read as mani (hand) + fold - and, as Carson observes with noted pleasure, totally "un-Kindle-isable" (qtd. in Sehgal), Nox is the book created anew in and for the digital age, innovating a conventional book form (the codex) by harking back to an ancient technique of book construction (the folded structure of the accordion book) that is frequently used in artists' books. Because the pages of Nox are not numbered while its paragraphs are, I use these numbers for referencing. As will become clear later on in this article, another way of navigating the text is through Catullus' poem I0I. I have therefore added Catullus' words as references.

The design is functional, moreover, in that the format draws the reader into an act of reading that feels intimate and personal, indeed, intimately personal. Although mass-produced, Nox looks like an artist's book. A camp object, then, ${ }^{2}$ it elicits a similar response, enticing the reader to treat it as if it were unique, auratic, and thus requiring delicate handling of its pages. Although it is possible to unfold the work in large gestures as if one were sowing rice, the boxed form rather invites careful manipulation, creating a space of close personal interaction between subject and object. Even though Carson's scrapbook was not intended for publication, Nox is made for a mass audience. Created on a Xerox machine, it contains photographs, paintings, drawings, collages, a letter her brother once wrote home, and bits of text retyped or composed, photocopied, and stapled, the textures of the handcrafted original painstakingly reproduced to evoke the analogue and its inscription of the passage of time with digital means. ${ }^{3}$ The 
found, archival documents are traces of the brother's life. Like the handwriting that Carson utilizes on several occasions throughout the book, they are indices of lived experience and of the real human bodies that produced them (and left them behind), of their perspectives, feelings, emotions, beliefs, and desires. In contrast, the use of paint, pencil, or crayon drawing, the layout and the play with typography all point to the work of the memorializer, as she is experimenting with various artistic means and forms. Brought together in the collage, documentation and experimentation inscribe subjectivity. Heightening the book's poignancy, they enable Nox to negotiate the public/private divide successfully by pulling the reader into a private act of remembering within the public space of publishing.

Reflecting her quest for a language to remember her brother, Carson's experimentation with form serves to explore their relationship, for instance in the typography. Throughout the work, different fonts are used, visually representing different voices and differentiating among genres. Thus, typeface inscribes what language describes, as Carson reproduces a telephone conversation she had with her brother, or quotes his words ("he called me professor or pinhead" [5.I; "mutam"; original boldface]), using the thick, dark lines of boldface to visually evoke what she calls Michael's "dark," "black, dense” voice (5.2; “cinerem”). Clearly, typeface is not neutral. As becomes evident when Carson transcribes his handwritten letter using all capitals and removing his punctuation, it inflects the text's meaning and reception. Slowing down the reading process by rendering the text more difficult to read, the juxtaposition of the two images of the same textual fragment shows lettering to shape meaning. Indeed, typographically adding emphasis, specifically "loudness," to the pieces of torn letter she pastes in the book, the all upper case transcription suggests anger by denoting shouting (cf. Robb).

This anger, however, is not just Michael's. Why indeed is the letter torn? And by whom? Earlier, framed by the question (without question mark) WHO WERE YOU - a question that situates Michael in the past, not as part of the present - Carson recalls her anticipation and disappointment as her mother, on her deathbed, returns all her letters to her, saying "you can have them all just one I want. / I wait. / The one your brother wrote from France .. ." (2.I; "vectus"). Torn and scattered across the pages of Nox, Michael's letter to his mother metonymically re-presents his disseminated ashes while metaphorically enacting a sibling rivalry that severs self and other, the living and the dead, the good and normal girl versus the criminal runaway brother. Othering, Barad writes, notwithstanding gender, race, and queer work on otherness that emphasizes the often very painful use of the term, "entails an indebtedness to the 'Other', who is irreducibly and materially bound to, threaded through, the "self"' (217). Dispersing identity, Carson's gesture of othering her brother is counteracted in the acknowledgment of their shared corporality. As she writes beneath a photograph showing a swing: "Places in our bones, strange brother" (3.3; "inferias," original italics). 
The juxtaposition of the fragmented handwritten letter with its typed transcription shows what gets lost in transcription. Handwriting, José van Dijck and Sonja Neef point out in the introduction to Sign Here! Handwriting in the Age of New Media, functions as a marker of authenticity, uniqueness, and personality. As they write, "Handwriting is traditionally regarded as an autography, as an un-exchangeable, unique and authentic 'signature' that claims to guarantee the presence of an individual writer during a historically unique moment of writing" (9). Requiring "reproduction technologies that are closer to those of images than to those of writing" (I0), handwriting is regarded as auratic because the hand and by extension the body, indeed the whole personality of the writer - is thought to leave its unique, personal trace in the autographed text: "subjectivity [. . .] is physically inscribed in the movement and the pressure of the pen led across the paper" (II). Representing his dead body, Michael's blue-penned letter is an authentic document that paradoxically makes him present throughout the book, whose pages thus come to bear the imprint not only of his physical body but also of his emotional state and personality traits, because, according to graphology, much about people's character, disposition, and attitudes can be derived from the characteristics, traits, and strokes of their writing.

The materiality of the written word and the differences between handwriting and typed writing are brought into play from the outset, literally inscribing the tension between subjectivity and iterability, singularity and repetition or reproduction. On the title page, Carson handwrites the name Michael six times, in bold strokes using a thick felt-tipped marking pen (of the type permanent marker). Then she pastes a thin strip of translucent paper in the middle of the page over the handwritten repetition of his name, vertically crossing it with the three words NOX FRATER NOX (NIGHT BROTHER NIGHT), typed below one another in small capital boldfaced letters. Using autography, typography, layout, and collage, the title page brings together subject and object (which is also a subject in more than one sense), subjectivity and languages in its material and visual dimensions, composing an epitaph that invokes (eternal) sleep while evoking the darkness in which he left his family about his life and whereabouts, the mystery he represents to his sister, and the confusion into which his unexpected death threw her. In English, the term Nox is a literary and poetic word, the (feminine) personification of night. In Latin, besides meaning night and darkness, the word also refers to nightfall, personified or as a goddess, and, figuratively, to confusion, obscurity, ignorance, unintelligibility, and death. Surrounding the Latin word for brother, the repetition of the word Nox materializes the truism that Nox is Carson's "night-work."

The insistent recursiveness of not just the name but also the very act of naming, of calling and calling again - indeed, of recalling - emphasizes process over product, doing over thing, memorializing over memorial. It also alerts us to a poetics and politics of repetition, citation, rewriting, and translation. The title page with its reiteration of the brother's name and evocation of Ophelia's 
"Good night, ladies, good night" in Hamlet (IV.5) signals from the onset that Nox is an intertextual space, an echo chamber - the resonating interior, as it were, of his sepulchre. Ophelia, it is worth noting, speaks these words in her madness as she mourns the death of her father, in Denmark, the country where Michael died. As stated in Nox, his wife "put his ashes in the sea, at sunset, near the castle of Helsinor" (7.2) - the very castle Shakespeare immortalized as Elsinore in his tragedy. Moreover, Ophelia's words have reappeared in T.S. Eliot's The Waste Land (I. I72), a poem whose first section is called, evocatively in this context, "The Burial of the Dead," ending with the famous quoted line (from Baudelaire) "You! hypocrite lecteur! - mon semblable, - mon frère!” (I. 76).

\section{Moving Words}

Carson's Latin title may be read as referring us back to Susan Howe's The Midnight (2003), a precursor multimodal elegiac memoir of the author's mother that is also a meditation on the materiality of the book. The Midnight, indeed, explores what Susan Barbour describes as "the elegiac potential of the book as object" and how a deceased person "can be remembered through their physical traces and metaphysical vestiges" (134, 139). Much in the same way as Carson's Nox (but without experimenting with the book form as such), Howe's The Midnight reproduces photographs, paintings, maps, handwriting, quotations from various sources, poems, lexical entries, and doctored images creating trompe-l'œil effects. As such, it exhibits a kindred poetics of collage. Thus The Midnight opens with a facsimile of the title page of Robert Louis Stevenson's The Master of Ballantrae, as seen through a tissue interleaf and accompanied by a prose text that is also a statement of poetics and, implicitly, a set of reading instructions, as it starts by commenting on the historical function of the tissue interleaf, which was "to prevent illustration and text from rubbing together," talks of the "transitional space between image and scripture" as a "zone of contention," and ends with the imperative "Give me a sheet," thereby suggesting the whole text is to be read as if written on such a sheet. Yet if Carson's title, Nox ("Night"), can be seen to gesture toward The Midnight as a precursor metabibliographical work, one that uses the book to reflect on the book as medium of remembrance, Nox metonymically also refers to the "dead" language Carson utilizes to memorialize her brother. Seeking to recollect Michael's memory, Carson constructs her epitaph using another epitaph, Catullus' poem I0I on the death of his brother, an elegy in which the Roman poet addresses the latter's mute ashes and that Carson has loved "since the first time I read it in high school Latin class" (7.I; "indigne”). On the first page of Nox, Carson gives us the ten-line Latin poem in its entirety, on a pasted sheet of lightly crumpled paper that has been soaked in tea to give it "a mysterious sepia overtone" and "add a bit of history" (Aitken), the italicized letters fading as if because of humidity. She then disassembles it throughout the book, parsing 
and glossing it word for word on the left-hand side of the page while saying things about her brother on the right-hand side of the page, her recollections mediated by the "collection of entries" (7.I; "mihi") that the poem provides. As such, Nox may be called a work of "unoriginal genius," to use Marjorie Perloff's term for "the wholesale citation of other people's words in order to make new works, by framing, citing and recycling already existing phrases, sentences, and even full texts" (as it reads on the back cover of Unoriginal Genius), a practice of citation, of appropriation, and rewriting that Kenneth Goldsmith has termed "uncreative writing," and that is central to twenty-first century poetics according to Perloff, "the logical form of 'writing' in an age of literally mobile or transferable text" (I7).

Born in 1950, Carson is a professor of classics, as well as an internationally acclaimed writer with a background in graphic design and a predilection for mixed media projects. Design and visual patterning have always been of concern to Carson. As she explains, "even when the thing I'm doing is just writing I try to make it into an object. Try to make it something to look at or experience as well as read, so I worry about the topography and spacing, and just the presentation of it" (Aitken). She has translated and modernized a number of classical texts, most recently Antigonick (2012), a version of Sophocles' Antigone that comes in handwritten capital letters on white pages, interspersed with translucent vellum pages with drawings by Bianca Stone that thus overlay the text. Carson's trade, we might then say, is in moving words carrying them across languages, transporting them to new contexts, making them convey meaning, but also "trying to make people's minds move, [. . .] make it [the mind] move somewhere it has never moved before" as she puts it (qtd. in Anderson). Moving words is, of course, the poet's art. According to the myth, following the death of Eurydice, Orpheus' songs moved trees and stones. Self-reflexive in that the work reflects on its own making - its poiesis - and contains its own theory of moving words, Nox can be seen as the culmination of this citational poetics, an elegiac, material citationality that evidences Perloff's claim that "in the beginning [of citationality] was translation" (I7). Distributing Catullus' words over the scroll, unpacking them vertically in lexical entries and unwrapping them horizontally across the page's fold, Carson literally moves the words in different directions to "prowl," as she puts it, the brother and the poem. As she elucidates, "I came to think of translating as a room, not exactly an unknown room, where one gropes for the light switch. I guess it never ends. A brother never ends. I prowl him. He does not end" (7.I; "indigne"). On the next page, across from the second entry for "frater," she continues:

Prowling the meanings of a word, prowling the history of a person, no use expecting a flood of light. Human words have no main switch. But all those little kidnaps in the dark. And then the luminous, big, shivering, discandied, unrepentant, barking web of them that hangs in your mind when you turn back to the page you were trying to translate. (7.I; "frater") 
A way of moving, prowling describes Carson's practice of translation as remembrance as a practice of "unoriginal" and "uncreative" writing that searches hesitantly or uncertainly by feeling about as in the dark. Materializing memory in a way similar to "the bowl at Exampaios" (7.I; "mihi”), which, Carson writes, was "made of the melted down arrowheads required of each Skythian by their king on pain of death" (I.3; "multa"), Nox tells the interrelated stories of the translation of the poem and the mourning of Michael as the fashioning of a beautiful object.

From the outset, Nox self-consciously unfolds, its opening words, "I wanted to fill my elegy with light of all kinds," emanating from and responding to the first word of Catullus' poem. "No matter how I try to evoke the starry lad he was, it remains a plain, odd history. So I began to think about history," Carson proceeds to write about her elegy in her opening paragraph (I.0; "multas"). The method of textual composition appears associative. Not only does meaning emerge from the juxtaposition of lexical entries with meditations on Michael and on the process of writing about him, but throughout Nox, Carson seems to let the words guide her in her quest as they arise. Tracing the words' literary tradition, collocation, idiom, and etymology, Carson elaborates a writing that tests itself as it probes its possibilities for sounding the muteness of her brother, as well as the muteness of the things he left behind, as opaque and inscrutable as Michael himself and epitomized by his disseminated ashes. "There is no possibility I can think my way into his muteness," Carson writes across the page of the second entry for inferias (8.5; "inferias"), a word she glossed on its first occurrence as "rites in honour for the dead; a tomb, sepulchre" (3.3; "inferias"). Reflecting on the difficulty of her enterprise, Carson's phrase echoes the mute ashes of Catullus' poem while defining Nox as addressing itself to muteness. For as Carson points out, "the word 'mute' [ . . .] is regarded by linguists as an onomatopoeic formation referring not to silence but to a certain fundamental opacity of human being, which likes to show the truth by allowing it to be seen hiding" (I.3; "per").

Nox can thus be seen to stage a hermeneutics of dialogical inquiry, one in which Catullus' words function as so many entries into the matter of Michael, with each word offering an opening onto or access to his "muteness." Thus Catullus' first word, "Multas," is explained to mean "many," "much," "an abundance of," "full, intense." According to the entry, it occurs in phrases such as "multa lux: broad daylight, multa nox: late in the night," to which Carson elegiacally adds, "perhaps too late," thus bending the first lexical entry toward her deceased brother, just as she closes the entry about Catullus's last word with the phrase "the Greeks have no precise word for this (but we call it 'night')." This unpacking of Catullus's poem, its unfolding across time, space, and language, is metaphor in the etymological sense of the term, carrying across, or over. It is "moving information," to use the term which Perloff coined in reference to Goldsmith's work, "pushing language around" and "being emotionally moved by that process" (Goldsmith, Uncreative I). Put in quotation marks, the word "night" refers us back to the title and thus to the beginning, to the need to start over. This beginning anew is necessary, Nox 
implies, because in the end, we are still in the dark about Michael, as his truth remains elusive, unknown and unknowable. Like the translation of the poem she never achieved to her liking, the brother remains beyond capture in (the English) language. "He refuses, he is in the stairwell, he disappears," Carson notes on the page opposite the entry for Catullus's last word, with the next page showing a strip of a blurry photograph of a tree in the open alongside what looks like the ghostly trace of the text on the previous page, a trompe-l'œil effect that makes the text linger, seemingly remaining a little longer in existence although becoming weaker, literalizing disappearance while manifesting a reluctance to end for, "A brother never ends" (7.I; "indigne"). The final pages show a blank page with just the faintest evocation of handwritten text next to an English translation of Catullus's poem, yet again on a tea-stained piece of paper and pasted on a dark grey page, burned at the edges and washed out, barely decipherable.

In elaborating the parallel between translating poem $\mathrm{IOI}$ and remembering her brother, Carson emphasizes (never-ending) process over (finished) product. Clearly, the process of seeking to understand is what matters; it is what unfolds between Catullus's Latin poem and Carson's English translation. It is also all there can be. Indeed, refusing easy access, the illegible poem offers no final revelation except that of palpable "overtakelessness" (I.3; "per") - Heidegger's Unumgängliche, that which cannot be dealt with and cannot be gotten around, but also (though not explicitly) Emily Dickinson's "overtakelessness of those / Who have accomplished Death" (Dickinson). Resisting closure, our desire for "other people to have a centre, a history, an account that makes sense" (3.3; "frater"), the poem's unreadability signifies untranslatability (of the poem) and incomprehensibility (of the brother). In the end, it shows Nox merely to have exhausted its possibilities for approaching its subject, with a snippet of the yellowed page functioning as the final point to this work while signifying the fragment that cannot be grasped in a comprehensive whole, and which, like the brother and the poem it metonymically represents, forever escapes us.

\section{Doing Things}

Evidently, then, Carson's Nox is more than a 'text'. As it were reversing Roland Barthes's programmatic "From Work to Text," it asserts itself as a literary work in its self-conscious reflection on its own materiality and on the intertextual practices it embodies. The disassembling of the poem, its decomposition into lexical entries is accompanied by a poetics of the fragment materialized by bits of letter, envelope, photographs, stamps, and the use of the paragraph as unit. For Carson, this practice of inquiry, of "asking about things," is doing history. As she explains, "History and elegy are akin. The word 'history' comes from an ancient Greek verb [. . . ] meaning "to ask." One who asks about things - about their 
dimensions, weight, location, moods, names, holiness, smell - is an historian" (I.I; "per"). Proceeding to elaborate on history as an inquiry into matter, she adds, "It is when you are asking about something that you realize you yourself have survived it, and so you must carry it, or fashion it into a thing that carries itself" (I.I; "per"). Nox, of course, is the thing that Carson fashions and carries. A heavy and unwieldy thing, it is like the mythological egg of myrrh containing the phoenix's ashes that the reborn phoenix carries to Egypt. Carson evokes the story as a metaphor for the historian's activity: "The phoenix mourns by shaping, weighting, testing, hollowing, plugging, and carrying towards the light" (I.I; "gentes"), she writes. A few pages later, she elaborates: "Herodotus is an historian who trains you as you read. It is a process of asking, searching, collecting, doubting, striving, testing, blaming and above all standing amazed at the strange things humans do" (I.3; “multa”).

Literally a strange thing, "treasurable and impractical" (Hapsis), Nox similarly trains its readers, its thingness giving sustained instruction and practice in how to approach otherness - the "muteness" of the brother no less than the "passionate, slow surface" of poem I0I (7.I; "indigne"), both of which remain beyond the "facts" that can be collected about them. Drawing the reader into the process of "prowling" what can only remain beyond comprehension, the bookishness of Nox involves an ethical command. In the already quoted essay "Thing Theory," Brown observes, "Adorno [. . .] understood the alterity of things as an essentially ethical fact. Most simply put, his point is that accepting the otherness of things is the condition for accepting otherness as such" (12). Nox defamiliarizes the act of reading. We cannot hold Nox in our hands, as we are wont to do with books, and the turning of pages feels and sounds different from what we are used to. Using the materiality of the book to engage the senses, Carson's book reminds the reader that reading is a material and affective practice, as well as a cognitive skill. Yet it is not just a matter of realizing how automated our handling of books has become. Instead, the difficulties we encounter in navigating Nox reveal that if people do things with books, so books do things to us. As material objects, books have agency and their materiality functions as a medium of sociality (Woodward, Understanding 172).

It is one of the insights of cultural material studies that, as Miller writes in Stuff, "objects make us, as part of the very same process by which we make them" $(60)$. Discarding the common view that people use things to represent them, to signify or symbolize something, Miller maintains that, on the contrary, stuff "creates us" (10): "Objects don't shout at you like teachers, or throw chalk at you as mine did, but they help you gently to learn how to act appropriately" (53). This view of material culture as doing things to us leads to an understanding of material culture as having an agency of its own (94).

Arguably, Nox demonstrates "how and why a more profound appreciation of things will lead to a more profound appreciation of persons," as Miller intends 
4 For a discussion of Nox in the light of kitsch, see Brillenburg Wurth ("Re-vision").

5 On the idea of multimodality or visuality as a "gimmick," see Gibbons' Multimodality. cultural material studies to do (6). This it does through the parallel Carson elaborates between translation and knowledge of the other as a material practice, which works by first establishing, then overcoming a series of dichotomies: subject and object, material and immaterial, body and mind, presence and absence, the living and the dead. Nox, its readers observe, "touches" you as you hold it in your hands. In the words of Canadian film and video artist Mike Hoolboom: "It touches you back," "weighs on its reader." In consequence, whereas Nox can be likened to other bookish books that fight back and seek, in Hayles's words, "to reawaken passion by introducing novelty into what have become routine physical encounters" (227), its aesthetics is not just an aesthetics of resistance but also an ethics of otherness. Showing things to have "vibrant" lives (Bennett), Nox reveals the interdependence of self and other, human and thing that constitutes both. Of course, Nox exploits the possibilities of the chosen medium even as it experiments with form. Taken together, the unusual format of the boxed accordion book and the visual, trompe-l'œil effects, which are deceiving to the eye but not to the touch (e.g., the suggestion of transparency and impression of text shining through on the next page, or of bits of paper pasted or stapled), make it a special object, as well as an ambiguous, boundaries-disrupting work whose materiality is at once real and counterfeit - replica, facsimile, the image of a book. As such, it hints of kitsch; ${ }^{4}$ some reviewers indeed speak of a clever gimmick to make money, yet concede, "it works" (Gerbrandy). ${ }^{5}$ As the locus of an encounter with otherness through the strangeness, beauty, pathos, and presence of the material, however, Nox moves its readers in new directions, inviting them to appreciate the shared materiality of people and things - the insight that "we too are stuff," as Miller phrases it (Stuff 6) - to admit the social world of people and the material world of things are interrelated, and to accept the process of self-alienation Miller designates with the term "objectification" (54 and passim). To cite Hoolboom: "I don't want to read Anne Carson's new book Nox, I want to be read by it. [. . .] I want to become this book."

\section{Reading "Out of the Box"}

In an article entitled "Multimodal Literature 'Moves' Us," Gibbons writes that "Multimodal printed literature [. . . ] not only moves us figuratively, it literally makes us move" (I2I). Inviting experimentation with how to read it, eliciting unconventional, "out of the box" ways of reading, Nox encourages the rediscovery of our own physicality, relocating our own bodily materiality in relation to the book, in effect putting "motion" back into "emotion." Searching for images of Anne Carson's Nox on the Internet, one finds many photographs of the bookin-a-box that display at once the bookishness of Nox and the creativity of its readers as they represent, stage, or record their encounter with it. There is the altered books artist Alexis Fedorjaczenko, who created a site-specific installation 
of Anne Carson's Nox in the context of an exhibition at the Hampden Gallery in Amherst in December 201I. There is also the performance of Nox with the participation of Anne Carson herself (and of Robert Currie), at the O, Miami Poetry Festival in April 201I, which involved Carson's book strewn about the space with dancers moving in and out of the physical text to the sound of Carson reading against a multiphonic backdrop in a choreography by Merce Cunningham Company dancer Rashaun Mitchell. (The performance premiered at the Boston Institute of Contemporary Art in July 2010). More interesting in the present context, however, are the performances of Nox that individuals perform at home. For instance, Andrew Kooman is a writer who notes on his weblog: "I had to rearrange my living room to read and appreciate Anne Carson's book Nox (see proof below)" (Kooman). As the book unfolds across floors, couches, shelves, and leather armchairs, it is remade into a diversity of site-specific installations, vernacular artworks in domestic settings that are shared with others through the medium of digital photography. On one blog, bearing the filename "into-theabyss.jpg," a picture of Nox tumbling down a dark stairway is posted, suggestive of Orpheus' descent into the underworld, while a picture of its blank verso spread out on a white bed sheet is accompanied by the words: "I was most captivated, oddly, by the empty sides of the pages. I sat for a few minutes pretending to read them, but of course, I was just staring at blankness. The disassembled story was on the other side, yet there seemed to be one here too" " Tree of Codes and Nox"). Similarly, on his website, Hoolboom accompanies a description of his encounter with Nox by pictures, starting with a photograph of the book with his hands opening it - appropriately, to the page on which Carson states that "Herodotus is an historian who trains you as you read" (.I.3; "multa"). He writes:

I open this tomb of a book, and I find the other part, the accordioned guts, waiting inside. It's the word they use in the book biz, don't you know, the guts. [. . .] And the guts come out of these covers clean and sharp and strangely uncut. I won't cut him. Is that what this book is saying? I can't cut my brother's body, or I can't cut him any more than I already have. All that is left of him are fragments, the already fading memories of him. And I'm going to wind them together in a single sheet, a single uncut shroud. To suggest, perhaps, some of the mysterious continuities that these broken pieces might possess. What is it that joins me to you?

Nox, in other words, is not only a work of unoriginal genius, but it elicits responses from its readers that may equally be called "unoriginal" and "uncreative," because it involves them in acts of recreation through the appropriation, recycling, and recontextualization of already existing material. Uncreative acts, it should be noted, are not devoid of creativity per se. As Goldsmith explains, they merely shift its locus to "choosing and reframing" (9), to the act of doing something with the material and the choices involved in the process, with the new "context [becoming] 
the new content" (3; emphasis in the original). Really quite "creative," then, they are acts of self-expression in which humans are drawn into the material world of things, react to them, and acknowledge their codependency. As such, they form explorations of relationality across and beyond the things-persons divide. Indeed, as the recurrence of the visual trope of the hand holding the page suggests, the process of objectification in which Nox pulls its readers equalizes thing and person: in the photograph's picture plane, they are brought not only together but also to the same level.

Moving people to produce performances of the book, Nox makes people do things with it, and with one another. As David Gauntlett writes in his book on the social meaning of creativity, "making is connecting because through making things and sharing them in the world, we increase our engagement and connection with our social and physical environments" (2). Showing Nox's bookishness to be social, such practices are evidence of its agency. Nox, indeed, invites or even requires certain practices. Its format demands you more or less carefully unfold the work, as you would an artist's book (even though it is a mass-produced object). As the images on the Internet attest, its thingness prompts you to share the experience of encountering its materiality. Although this sharing is facilitated by digital technologies and social media, it is Nox that moves people to share their love or fascination with others. Touching you as you touch it, Nox creates a web of relations, a network in which people and things are "entangled," as lan Hodder puts it, acting and participating in it, and "having the ability to make other actors do unexpected things" (Latour 129; original emphases).

\section{Conclusion}

In making her epitaph, Carson takes upon herself the Antigonean task of remembering and reburying her wandering brother and her late mother's lost son. Yet if Carson performs a rite of mourning with the making of her book, Nox is ultimately less about working through her own emotions than it is about the quest for the (br)other. Whereas grief, Judith Butler points out in Precarious Life, "displays the thrall in which our relations with others hold us" (23), Carson did not want to explore grief, for that "would have made it a book about me, and I didn't want that" (qtd. in Sehgal). Instead, she says Nox is "about understanding other people and their histories as if we are all separate languages" (ibid.).

Because of its associations with the self-sacrificing, self-effacing mother, the selfless focus on the other is construed as a gendered virtue in our society. It would certainly go too far to claim this quality makes Nox a work of literature gendered feminine, yet it is clear its bookishness is operating on another front than that of the battle identified by Pressman. An elegy for her prodigal brother, Nox is rather a eulogy for the book, praising its capacity to remain even after it has disappeared, reborn like the phoenix, risen again like Lazarus. A book in the form 
of an image of a book, Nox exploits the technological possibilities of the digital age to simulate the strangeness, concreteness, and indecipherability of the other and, representing loss as the stuff of life itself, entangles its readers in sociality by moving them affectively, cognitively, and physically.

Radboud University Nijmegen, The Netherlands I.plate@let.ru.nl

\section{Acknowledgments}

Versions of this article were presented at conferences in England, The Netherlands, and the USA. I wish to thank Kaye Mitchell, the anonymous reviewers, and the members of the Beatrice Bain Research Group at UC Berkeley for their constructive feedback on my text.

\section{Works Cited}

Aitken, Will. "Anne Carson, The Art of Poetry No. 88." Interview. The Paris Review I7I (Fall 2004): n. pag. Web. 27 Aug. 2014.

Anderson, Sam. "The Inscrutable Brilliance of Anne Carson." The New York Times Magazine (I4 Mar. 20I3): n. pag. Web. 3 Oct. 2014.

Barad, Karen. "On Touching - The Inhuman That Therefore I Am." Differences: A Journal of Feminist Cultural Studies 23.3 (2012): 206-23. Web. 19 Nov. 2014.

Barbour, Susan. “'Spiritual Hyphen': Bibliography and Elegy in Susan Howe's The Midnight.” Textual Practice 25.I (201I): I33-55. Web. I2 May 2014.

Barthes, Roland. "From Work to Text." Image Music Text. Trans. Stephen Heath. London: Fontana, 1977. 155-64.

Bennett, Jane. Vibrant Matter: A Political Ecology of Things. Durham: Duke UP, 20I0. Print. Bray, Joe, Alison Gibbons, and Brian McHale, eds. The Routledge Companion to Experimental Writing. London: Routledge, 2012.

Brillenburg Wurth, Kiene. "Re-vision as Remediation: Hypermediacy and Translation in Anne Carson's Nox.” Image [\&] Narrative 14.4 (20I3): 20-33. Print.

Brooke-Rose, Christine. Stories, Theories and Things. Cambridge: Cambridge UP, in 1991. Print.

Brown, Bill. "Thing Theory.” Critical Inquiry 28.I (Autumn 200I): I-22. Print.

Butler, Judith. Precarious Life: The Powers of Mourning and Violence. London: Verso, 2004. Print.

Carson, Anne. Nox. New York: New Directions, 20I0. Print.

Carson, Anne, Bianca Stone, and Robert Currie. Antigonick (Sophokles). New York: New Directions, 2012. Print. 
Carson, Anne. Chor. Rashaun Mitchell. NOX: A Collaborative Poetry and Dance Performance. O, Miami Poetry Festival, The Moore Building, 7 Apr. 20II. Performance. Danielewski, Mark Z. House of Leaves. New York: Pantheon, 2000. Print.

Dickinson, Emily. "The Overtakelessness of Those." Complete Poems (1924): n. pag. Bartleby.com. Web. 3 June 2014.

Dijck, José van and Sonja Neef. "Sign Here! Handwriting in the Age of Technical Reproduction: Introduction.” Sign Here! Handwriting in the Age of New Media. Ed. Sonja Neef, José van Dijck, and Eric Ketelaar. Amsterdam: Amsterdam UP, 2006. 7-17. Print.

Drucker, Johanna. The Century of Artists' Books. New York: Granary Books, 1995. Print.

___ "Intimate Authority: Women, Books, and the Public-Private Paradox." The Book as Art: Artists' Books from the National Museum of Women in the Arts. Ed. Krystyna Wasserman. New York: Princeton Architectural Press, 2007. 14-17. Print.

Fedorjaczenko, Alexis. Philyra, a Site-Specific Installation of Anne Carson's Nox. Exhibition "A Novel Idea. Not only Curated by Anne LaPrade Seuthe and Sally Curcio. Hampden Gallery, Fine Arts Center, University of Massachusetts, Amherst. II Dec. 2011-19 Feb. 2012.

Foer, Jonathan Safran. Extremely Loud and Incredibly Close. New York: Houghton Mifflin, 2005. Print.

_- _ Tree of Codes. New York: Visual Editions, 20I0. Print.

Friedman, Ellen G. "Sexing the Text: Women's Avant-Garde Writing in the Twentieth Century.” Bray, Gibbons, and MacHale I54-67.

Gauntlett, David. Making Is Connecting: The Social Meaning of Creativity, from DIY and Knitting to YouTube and Web 2.0. Cambridge: Polity, 201I. Print.

Gerbrandy, Piet. "We Call I not only Night'." Atheneum Boekhandel (I8 May 20I0): n. pag. Web. 7 May 2014.

Gibbons, Alison. Multimodality, Cognition, and Experimental Literature. London: Routledge, 2012. Print.

—__ . "Multimodal Literature and Experimentation.” Bray, Gibbons, and MacHale 420-34.

“Multimodal Literature 'Moves' Us: Dynamic Movement and Embodiment in VAS: An Opera In Flatland." HERMES: Journal of Language and Communication in Business 4I (2008): I07-24. Print.

—_ - "Multimodal Metaphors in Contemporary Experimental Literature." Metaphor in the Social World 3.2 (2013): 180-98. Print.

Goldsmith, Kenneth. Uncreative Writing. Managing Language in the Digital Age. New York: Columbia UP, 20II. Print.

Hall, Steven. The Raw Shark Texts. New York: Canongate, 2007. Print.

Hallet, Wolfgang. "The Multimodal Novel: The Integration of Modes and Media in Novelistic Narration." Narratology in the Age of Cross-Disciplinary Narrative 
Research. Ed. Sandra Heinen and Roy Summer. Berlin: Walter de Gruyter, 2009. 129-53. Print.

Hapsis, Emmanuel. "Building Stories: Chris Ware's Antidote to Our Distracted Times.” (28 Nov. 2012): n. pag. Web. 26 May 2014.

Hayles, N. Katherine. "Combining Close and Distant Reading: Jonathan Safran Foer's Tree of Codes and the Aesthetic of Bookishness." PMLA I28.I (Jan. 20I3): 226-31. Print.

Heidegger, Martin. Poetry, Language, Thought. New York: Harper and Row, 1975. Print.

Hodder, lan. Entangled: An Archaeology of the Relationships Between Humans and Things. Oxford: John Wiley \& Sons, 2012. Print.

Hoolboom, Mike. "Anne Carson” (Undated): n. pag. Web. 10 Oct. 2013.

Howe, Susan. The Midnight. New York: New Directions, 2003.

HowStuffWorks. "Can You Explain the Basic Difference between Analog and Digital

Technology?” (I Nov. 2013): n. pag. Web. I Nov. 2013.

Jenkins, Henry. Convergence Culture: Where Old and New Media Collide. New York:

New York UP, 2006. Print.

Kooman, Andrew. "Nox, Anne Carson.” Online Posting (3 Feb. 20II): n. pag. Web. 10 Oct. 2013.

Latour, Bruno. Reassembling the Social: An Introduction to Actor-Network-Theory.

Oxford: Oxford UP, 2007 (2005). Print.

Miller, Daniel. Stuff. Cambridge: Polity Press, 2010. Print.

Perloff, Marjorie. Unoriginal Genius: Poetry by Other Means in the New Century. Chicago:

The $U$ of Chicago P, 2010. Print.

Pessl, Marisha. Special Topics in Calamity Physics. New York: Viking, 2006. Print.

Pressman, Jessica. "The Aesthetic of Bookishness in Twenty-First-Century Literature.” Michigan Quarterly Review 48.4 (2009): 465-82. Print.

Robb, Alice. "How Capital Letters Became Internet Code for Yelling." The New Republic (I7 Apr. 2014): n. pag. Web. 3 June 2014.

Sehgal, Parul. "Anne Carson: Evoking the Starry Lad.” The Irish Times (I9 Mar. 20II): n. pag. Web. 3 June 2014.

Sontag, Susan. "Notes on Camp." Against Interpretation and Other Essays. London: Deutsch, 1987. 275-92. Print.

Teicher, Craig Morgan. "A Classical Poet, Redux: PW Profiles Anne Carson." Publishers' Weekly (29 Mar. 2010): n. pag. Web. II May 2014.

"Tree of Codes and Nox: Familiar Media". Other Side of Eyre - or (I5 Nov. 2012): n. pag. Web. 3 June 2014.

Trimpi, Wesley. "The Definition and Practice of Literary Studies." New Literary History 2.I (Autumn 1970): 187-92. Print.

Wagner, Heather. "Jonathan Safran Foer Talks Tree of Codes and Conceptual Art." Vanity Fair (I0 Nov. 20I0): n. pag. Web. 6 Nov. 2013.

Woodward, Ian. Understanding Material Culture. London: Sage, 2010 (2007). Print. 